\title{
Mitigating Climate Challenges: The Role of Social Studies Education
}

\author{
Dr. Isaac Atta Kwenin \\ Lecturer \\ Department of Business \& Social Sciences Education, \\ University of Cape Coast, Ghana, West Africa
}

\begin{abstract}
The main focus of this study was to explore the role of Social Studies education in mitigating climate challenges. The mixed method approach was employed to carry out this study. All the 154 Social Studies teachers in 79 public Junior High Schools (JHSs) from the Cape Coast Metropolis participated in the study. The researcher used questionnaire and semi-structured interview guide to collect information from these participants. Responses from the questionnaires were analysed using the Statistical Product for Service Solution (version 22.0) software and the outcomes were presented in the form of frequencies, percentages, means and standard deviation. The findings from the study indicate that the Social Studies curriculum at the senior high school level does not adequately cover climate related issues. Although Social Studies education focuses on the physical environment and helps to address environmental challenges, one would expect that the curriculum would make adequate provision for such a critical component of the environment, but this is not the case as the curriculum covers less environmental-related issues. Although Social Studies teachers are the front liners when it comes implementing climate-related issues in the Social Studies curriculum, they are not adequately equipped with the knowledge, skills and competencies required for effective transmission of same to learners. At best, some of the teachers had climate related knowledge from subjects other than social studies, the knowledge they had acquired was not sufficient enough for their effective application in the classroom. It was recommended that integration of more climate-related topics and issues in a transdisciplinary manner into the Social Studies and other related curricula such as science, citizenship education, geography and human rights education, at the various levels of education in Ghana would be of great help. Teacher education institutions that prepare Social Studies teachers at the various levels of higher education in Ghana such as the colleges of education and the universities should adequately include climate change related topics in their curricula. It is crucial to strengthen teachers' and educators' capacities to deliver accurate information, integrate local content, promote critical thinking about climate change and take action on climate change mitigation and adaptation.
\end{abstract}

Keywords: Climate Change, Environmental, Integration, Pedagogies, Social Studies.

DOI: $10.7176 / \mathrm{JEP} / 12-14-06$

Publication date:May $31^{\text {st }} 2021$

\section{Introduction}

One of the best ways of dealing with the challenges of climate change is the integration of climate change into the curriculum (Inter-governmental Panel on Climate Change, 2008), specifically, the Social Studies curriculum. This is because the Social Studies curriculum contributes immensely to the holistic development of the student by raising students' environmental awareness and by equipping them to recognize the impact of their actions on the environment. By educating learners on environmental awareness and participation in environmental development, students would be able to address the environmental challenges that confront our society. The basic objective of Social Studies education is the development of concerned, reflective and competent citizens who are better positioned to solve environmental problems from diverse angles (Martorella, 1994). In Ghana, Social Studies education was specifically designed and included into the school curriculum at all levels of education in Ghana because of its unique role in training individuals, preparing and qualifying them for job opportunities, integrating people into societies and teaching them the values and morals of the society (Ghana Education Service GES], 2010). It is based on this that the GES (2010) sees the objectives of Social Studies as developing the cognitive, affective and psychomotor domains of individuals to ensure that they are better positioned to solve societal problems from diverse angles. Students are made aware of current social and environmental problems, and the strategies they should adopt to address them. By implication, Social Studies provides a platform where people find solutions to social and environmental problems in their communities. It is against this background that students in senior high schools are being equipped with the necessary knowledge, skills, values and attitudes to explore practical means to help combat the adverse effects of climate change. This calls for the need to explore the adequacy of the JHSs Social Studies curriculum in meeting the challenges posed by climate change in Ghana. 


\section{Problem statement}

Climate change is one of the major environmental problems. Global changes in climate are unequivocal, and already causing significant harm, as well as posing great risks to our future. The actions individuals take influence the magnitude of global warming and the amount of greenhouse gas emissions. Therefore, educating students about the causes, effects and measures to mitigate the climate challenges is crucial, and the use of Social Studies education which is environmentally oriented has been found to be instrumental in providing students with the tools for dealing with environmental challenges posed by climate change. This is because, Social Studies education, has the creation of learners' awareness of environmental problems and the provision of the necessary knowledge, skills, and attitude towards the resolution of environmental problems as its major focus.

According to Resnik (2006) and Benavot (2002), there is consensus that Social Studies education is and remains an effective means for addressing environmental challenges. In Ghana, Social Studies is perceived as the integrated study of the social sciences and humanities to promote civic competence. Within the school system, Social Studies provides a coordinated and systematic study drawing from such disciplines as anthropology, economics, geography, history, political science, psychology, and sociology (Banks, 2000). It implies that the country requires not only citizens who can think critically and constructively, but also those with sound social, political, and environmental orientation who can contribute successfully to the eradication of environmental problems including climate change, hence, the inclusion of Social Studies into the Ghanaian education system (GES, 2010). In this regard, it is expected that the Social Studies curriculum at the senior high school level which is poised in dealing with environmental challenges will cover adequately the concept of climate change and equip students with the skills of solving the associated problems of climate change.

However, a cursory review of the Junior High School Social Studies curriculum reveals that the subject is inadequate in terms of content and experiences required by students to address the challenges of climate change. The curriculum seems to provide little opportunity to address moral issues, human behaviour, as well as attitudinal issues that relate to climate change. For example, in the senior high school Social Studies curriculum, the concept of climate change is not explicitly covered. The major topic that relates to climate change is: our physical environment and environmental challenges which is taught in Unit 1 of Section 1 of Year Three (GES, 2010). Here, although emphasis is put on the environment, it is more concerned with explaining the term "physical environment", examining how man is influenced by the environment in Ghana and the circumstances under which this occurs, as well as how some countries have adapted the environment to their needs and the ways by which Ghana could also make similar adaptation, without specific reference to climate change. From the above, it is clear that the content of Social Studies does not make it responsive to the challenges of climate change. The implications are that students are ill-prepared to tackle the challenges of climate change. It is against this backdrop that the present study seeks to assess the adequacy of the JHS Social Studies curriculum in meeting the challenges of climate change in Ghana.

\section{Objectives of the study}

The primary focus of this study was to explore the content adequacy of the Junior High School Social Studies curriculum in dealing with climate change. Specifically, the study sought to:

i. examine the adequacy of the JHS Social Studies curriculum in covering climate change issues;

ii. explore methods recommended by the Social Studies Curriculum for Social Studies teachers to use in teaching climate-related issues in the curriculum;

iii. explore Social Studies teachers' level of knowledge about climate change;

iv. ascertain Social Studies teachers' views on the challenges of Social Studies education in responding to climate change issues;

v. recommend measures that should be put in place to ensure that the JHS Social Studies curriculum adequately prepare JHS students to respond to the challenges of climate change

\section{Research questions}

The following research questions were considered to guide the study:

i. How adequate does the JHS Social Studies curriculum cover climate change issues?

ii. What methods in the curriculum do Social Studies teachers employ in teaching climate change issues?

iii. What is Social Studies teachers' level of knowledge about climate change issues?

iv. What is the perception of Social Studies teachers on the challenges of the Social Studies in responding to climate change?

\section{Research design}

This study employed the mixed methods approach using the convergent parallel design which enabled the investigator to collect both the quantitative and qualitative data at the same time, analysed and presented them separately but blended them at the data interpretation stage. Use of multiple data sources and methods of data 
gathering increased the credibility and dependability of the data. This is because the strengths of one source compensate for the potential weaknesses of the other (Johnson \& Onwuegbuzie, 2006). Mixed-methods also provided stronger evidence for the conclusions of my study through convergence and corroboration of findings. The purpose of using a mixed method design was to use both the responses obtained from the questionnaire and those from the interviews to provide a comprehensive analysis of the research questions asked. Secondly, I used the results from one instrument to confirm or corroborate findings from the other (Creswell, 2003).

Since the investigator collected data at one point in time, the cross-sectional descriptive survey was employed. The investigator collected data from the teachers at one point in time ( $1^{\text {st }}$ and $15^{\text {th }}$ November, 2019). Cross-sectional surveys may use both questionnaire and interviews to gather information from respondents (Babbie, 2007), Ary, Jacobs, Razavieh, \& Sorensen 2006; Creswell, 2003). Another major reason for using this design was that it offered the investigator the opportunity to collect a wide scope of information from a large population. It was also used because of its usefulness in assessing practices, attitudes, knowledge and beliefs of the population in relation to supervision of instruction in Social Studies (Babbie, 2007). The results from this study not only gave an indication of the magnitude of the problem at a particular point in time, but also provided a basis for proposing appropriate measures to deal with the problem. On the other hand, it did not provide opportunity for respondents to answer questions thoroughly across the various public JHSs in the Cape Coast Metropolis.

\section{Population for the study}

The 154 Social Studies teachers in 79 Junior High Schools (JHSs) in the Cape Coast Metropolis during the 2019/2020 academic year constituted the population of the study. Two different instruments were used to gather data for the study. The first was a questionnaire developed by the investigator and consisted of five sections based on the purpose of the study. Section A gathered personal data including teachers' teaching experience and academic qualification. Sections B, C, D, and E covered Social Studies teachers' level of knowledge about climate change; the adequacy of the JHS Social Studies curriculum in covering climate change issues; methods Social Studies teachers use in teaching climate related issues in the curriculum; and teachers' perceptions on the challenges students are likely to face in responding to climate change issues. A 5-point Likert-type scale was used: $5=$ strongly agree, $4=$ agree, $3=$ uncertain, $2=$ disagree, $1=$ strongly disagree. Items were structured along the lines of the Likert scale because it enabled the respondents to indicate the degree of their acceptance to a given statement. It was also easy to construct, administer, and score (Kimmon, 1990). All the items of the questionnaire were in line with the literature reviewed.

The investigator used interviews to complement the questionnaire administration because the interviews enabled the investigator to better understand the perspectives of the teachers regarding climate change. Interviews also allowed a wide range of respondents' understanding to be explored, and helped reveal important aspects of climate change in Social Studies. Semi-structured interviews allowed the respondents to focus on the research questions, yet opened up new avenues for further questions. The semi-structured interview consisted of 10 items which focused on the first four research questions. Furthermore, the interviews were intended to provide additional information that would be difficult to capture using a questionnaire. Interviews were also appropriate because they allowed exploration of variables under investigation in greater detail, and so complemented the survey (Creswell, 2003).

\section{Validity of the Instruments}

This study incorporated the procedures of content validity. The claim for content validity was based on the examination of the survey instrument by educational professionals. The investigator took the following steps in order to ensure content validity of the questionnaire.

1. The design of the questionnaire and the interview protocol was influenced by the literature reviewed by the investigator and the conceptual framework which ensured that the questionnaire and interview protocol reflect the representative themes.

2. The questionnaire and the interview protocol were initially reviewed by the investigator's supervisors who commented on the structure of the questionnaire, the wording and repetition of similar items. The aim was to reveal any ambiguity, threatening questions and other problems which needed to be sorted out before piloting the questionnaire.

3. Researchers (Gall, Borg, \& Gall, 1996) advocated pilot-testing the survey instrument prior to its delivery to the participants. In this regard, the instrument was piloted with a group of Social Studies teachers (not part of the sample) in JHSs in the Cape Coast Metropolis. These individuals reviewed the instrument, commented on its appropriateness, and made suggestions for change. The feedback helped to ensure that the instrument measured what it was intended to measure. 


\section{Reliability of the Questionnaire}

The development of multi-item rating scale required evaluation of the scale for reliability. According to Greenleaf (1992), a multi-item scale should be evaluated for accuracy and applicability. In relation to this study, this involved testing for internal consistency among the items measuring each construct. In order to determine whether the investigator succeeded in testing the constructs the investigator sought to test the individual items were tested for reliability. This was compiled by computing the Cronbach's alpha coefficient which indicated the degree of item-total correlation. It varies from 0 to 1 and a value of 0.6 or less generally indicates unsatisfactory internal-consistency reliability and therefore helps in deciding whether to delete an item from the list and whether the elimination improves the corresponding alpha values (Parasuraman, Zeithaml, \& Berry, 1988).

The investigator used the Cronbach's alpha against the background that its values tend to increase with an increase in the number of items in a scale. Individual items with corrected item-to-total correlation below 0.6 were eliminated. In all, the total number of items eliminated was 14 . The items under each construct therefore possessed item-total-correlation coefficients.

\section{Data Collection Procedure}

The investigator personally visited the various schools and administered the questionnaires to the respondents. The investigator also personally conducted face-to-face interviews with 10 teachers. The interviews were audiorecorded and transcribed within the day of the interview. Finally, the investigator played back the recorded conversation to the interviewees to make sure they agreed to what had been shared and also to ensure that the conversation was properly recorded. Each participant was given his or her respective transcript for memberchecking, and to verify transcript content.

\section{Data Processing and Analysis}

Data were transferred to Statistical Product and Service Solution (SPSS version 22.0) software after coding the data. The analyses were done using frequencies and percentages for all the research questions. The interview responses from the interviewees were analysed personally with cross-case analysis procedure after transcription. In this approach, responses to a common question from all interviewees were analysed together. Common themes across respondents were then identified, analysed and interpreted item by item. As part of the analysis, the investigator replayed the audio recordings of each respondent and transcribed them by hand on paper. The investigator transcribed sentences and phrases directly to avoid misinterpretation of the sense or meaning of information respondents provided. He again read through the responses for each item across for all the teachers and recorded the key ideas. Responses from each question were grouped together and analysed on central issues. If an interviewee provided a response to a particular question but was found to answer a different question, he transferred the particular response to include it in the responses for the latter.

\section{Ethical consideration}

Ethics in research insist on safeguards to protect participants' identities. In the case of this study, respondents were asked not to give personal or private information about themselves. Copies of the questionnaire and interview schedule were given to the teachers for their personal perusal for the purposing of making sure that the process of data collection and the information required would not infringe on their rights and also create ethical problems to the schools. After they had gone through the consent form, they shared their readiness to offer the requisite information for the study.

\section{Discussion of findings}

The following section presents the main results obtained from the collection of the data according to the research objectives.

\section{Adequacy of the Social Studies curriculum in dealing with climate}

This section dealt with some key climate related issues which are the basis of climate change education. The Social Studies teachers were required to indicate the extent to which the Social Studies curriculum adequately or inadequately covers the key issues in climate. The outcome of their views gathered with the questionnaire and presented in Table 1. The respondents were also interviewed on the adequacy of the Social Studies curriculum in covering climate related issues. The views that emerged buttress the results obtained from the questionnaire. 
Table 1: Views on Teachers on the Adequacy of the Social Studies Curriculum in dealing with Climaterelated Issues

\begin{tabular}{|c|c|c|c|c|c|c|c|c|}
\hline \multirow[t]{2}{*}{ Social Studies curriculum adequately covers } & \multicolumn{2}{|c|}{ Adequate } & \multicolumn{2}{|c|}{ Neutral } & \multicolumn{2}{|c|}{ Inadequate } & \multirow[t]{2}{*}{ Mean } & \multirow{2}{*}{$\begin{array}{r}\text { Std } \\
\text { dev. }\end{array}$} \\
\hline & $\mathbf{N}$ & $\%$ & $\mathbf{N}$ & $\%$ & $\mathbf{N}$ & $\%$ & & \\
\hline Knowledge about the meaning of climate change & 1 & 0.6 & 0 & 0 & 153 & 99.4 & 2.99 & 0.16 \\
\hline Causes of climate change & 5 & 3.2 & 0 & 0 & 149 & 96.8 & 2.94 & 0.36 \\
\hline Impacts of climate change & 3 & 1.9 & 0 & 0 & 151 & 98.1 & 2.96 & 0.28 \\
\hline Mitigation strategies for climate change & 0 & 0 & 0 & 0 & 154 & 100.0 & 3.00 & 0.00 \\
\hline Adaptation strategies for climate change & 0 & 0 & 0 & 0 & 154 & 100.0 & 3.00 & 0.00 \\
\hline Structure of the earth's atmosphere & 13 & 8.4 & 2 & 1.3 & 139 & 90.3 & 2.82 & 0.57 \\
\hline Composition of the earth's atmosphere & 13 & 8.4 & 2 & 1.3 & 139 & 90.3 & 2.82 & 0.57 \\
\hline The planetary system & 11 & 7.1 & 0 & 0 & 143 & 92.9 & 2.86 & 0.52 \\
\hline Elements of weather and climate & 4 & 2.6 & 0 & 0 & 150 & 97.4 & 2.95 & 0.32 \\
\hline
\end{tabular}

\section{Source: Field Data, 2019}

The respondents of the view that most of the issues that are taught in Social Studies at the JHS level relate more with the social environment than the natural environment. For instances, one interviewee indicated that “... not at all. The JHS Social Studies curriculum is more of family issues, social institutions, and the likes. It does not focus on the natural environment at all. Even if it does, the emphasis is minimal which is not greater enough to deal with the menace of climate change". Another interviewee also said that, "when it comes to Social Studies and climate change, there is no link. Most of the topics that we teach are unrelated to climate issues although Social Studies is supposed to study the environment and man's impact on the environment. What it does is little emphasis on the natural environment and more emphasis on other issues in Ghana and the world at large.

Others also believed that although the Social Studies curriculum does not directly relate to climate related issues, there are some topics that deal with environmental issues of which climate related issues are part. For instance, one teacher said that "Social Studies deals with man in his environment. Therefore, everything about the environment is of interest to social studies. So if climate change or climate related topics are not found in the syllabus, it does not mean that the syllabus ignores climate change. There are other topics that are environmentally relevant and indirectly address the issue of climate change. For example, the issue of afforestation, environmental degradation and environmental pollution are all related to climate change. So, for me, the curriculum deals with climate change just that climate change is not explicitly stated in the curriculum".

It can be deduced from the responses from the survey and interview that although climate change is not explicitly covered in the Social Studies curriculum, there are other equally important environmentally-related topics such as degradation and environmental pollution which relate to climate change.

\section{Teachers' level of knowledge about climate change}

This section explored the level at which social studies teachers have gained knowledge that will be helpful in teaching students climate-related concepts in Social Studies. The section therefore enquired from the teachers the level of academic qualification they have acquired in relation to climate change.

Table 2: Teachers' level of knowledge about climate change

\begin{tabular}{lll}
\hline I have acquired & No. & $\%$ \\
\hline Bachelor of Education Degree in Social Sciences & 9 & 5.8 \\
Bachelor of Education Degree in Social Studies & 7 & 4.5 \\
Bachelor of Arts in Social Sciences & 8 & 5.2 \\
Bachelor of Arts in History & 5 & 3.2 \\
Post Graduate Diploma in Education (Social Studies) & 11 & 7.2 \\
Diploma in Basic Education & 114 & 74.1 \\
\hline Total & 154 & 100.0 \\
\hline
\end{tabular}

Source: Field Data, 2019

Table 1 shows that majority of the teachers 114(74.1\%) who teach social studies holds Diploma in Basic Education whilst few, 7(4.5\%) have Bachelor of Education degree in Social Studies. It also shows that 11(7.2\%) have Post Graduate Diplomat in Social Studies Education. This is a clear indication that majority of the teachers who teach Social Studies do not have the requisite minimum academic qualification in Social Studies. Although $74.1 \%$ hold diploma in basic education, these teachers were not specifically trained in the content of social studies education but rather they received general knowledge that is relevant for teaching at the basic level of education in Ghana of which social studies is included. This will not ensure effective teaching of climate-related concepts in Social Studies. Even the few who possess the requisite qualification in social studies, it is not clear whether the content of education the received in Social Studies adequately cover climate-related issues including climate change. This is due to the variation of the content of Social Studies education at the various tertiary levels of education in Ghana (Kwenin, 2019). The implication is that they would lack extensive knowledge on 
issues that relate to climate change and would also be underprepared in content to fully address climate related issues in their classrooms. Wise (2010) indicated that few teachers take college-level courses related to climate change, and generally learn about climate change on their own.

In addition to the data gathered with the questionnaire, the teachers were interviewed in order to seek more clarification about their knowledge in climate-related issues. The views of the teachers show that few of knowledge they have acquired emphasised climate-related education. For instance, one teacher said that, "... most of the courses I read in school were not strictly in Social Studies education but in other subject areas and they had no strong bearing on climate education". Another teacher also indicated that, "yes, we did something in geography but none of the topics talked about the climate. The topics were more or less on physical landforms and the likes".

When they were further asked as to whether they would be able to teach climate related topics in Social Studies, one of them answered in affirmative and indicated that, "that shouldn't be a problem because, the tertiary institutions provide generalized body of knowledge which serves as good platform for teachers to build their knowledge. So once you have the basis, you can easily fall on any textbook or research outcome on any topic you want to teach and prepare yourself for that lesson". A similar view was shared by another teacher when he indicated that, "topics offered during teacher preparation are quite different from topics we teach in the classrooms, so as for the diploma or degree, we will acquire them but when it comes to the actual delivery in the classroom, we read books and other relevant materials in order to teach". Another teacher also said that, "you can't rely solely on the knowledge you gain in school to teach Social Studies because most of the things we are taught whilst in school are unrelated to the things we teach in the classroom. The topics and approaches are different, so the climate you are talking about, I for instance, have never met it, yet I teach some aspects of it".

It is clear from both the questionnaire and interview that majority of the Social Studies teachers did not have adequate level of knowledge and experiences in climate related-issues which are pre-requisites for effective teaching of climate related issues in Social Studies. Although they taught climate related issues in Social Studies, they relied heavily on their own information from various sources to ensure effective teaching. It must be noted that without a professionally qualified and experienced Social Studies teacher, Social Studies education can hardly achieve its primary purpose of facilitating students' understanding of their environment and equipping them with the relevant tools for address environmental challenges.

As a matter of fact, teachers whose knowledge base in a particular subject matter is inadequate principally cannot positively impact on students' understanding of that subject matter. Thus, the role of the teacher, collectively and individually, is crucial in teaching since teachers' unfamiliarity about what climate change is can influence their ability to carry out effective climate education in the classroom. This is particularly true when there is a general notion that everybody can teach social studies.

\section{Methods of teaching climate Change through Social Studies Education}

This section explored the various methods used by Social Studies teachers to teach climate-related. The outcome shows that teachers use variety of teaching techniques such as the discussion $(\mathrm{N}=154, \mathrm{M}=3.00, \mathrm{SD}=0.00)$, role play $(\mathrm{N}=154, \mathrm{M}=1.06, \mathrm{SD}=0.36)$, the use of resource persons $(\mathrm{N}=154, \mathrm{M}=1.10, \mathrm{SD}=0.45)$, brainstorming $(\mathrm{N}=154, \mathrm{M}=1.15, \mathrm{SD}=0.51)$ and problem solving method $(\mathrm{N}=154, \mathrm{M}=1.22, \mathrm{SD}=0.59)$ to teach climate-rated topics in Social Studies. Discussion method is viewed by teachers as relevant method of promoting the exchange of information and ideas between students and teachers.

Table 2: Methods of teaching climate change through Social Studies education

\begin{tabular}{|c|c|c|c|c|c|c|c|c|}
\hline \multirow{2}{*}{$\begin{array}{l}\text { Methods of teaching climate related } \\
\text { issues through Social } \\
\text { education }\end{array}$} & \multicolumn{2}{|c|}{ Appropriate } & \multicolumn{2}{|c|}{ Neutral } & \multicolumn{2}{|c|}{ Inappropriate } & \multirow[t]{2}{*}{ Mean } & \multirow[t]{2}{*}{ Std dev. } \\
\hline & $\mathbf{N}$ & $\%$ & $\mathbf{N}$ & $\%$ & $\mathbf{N}$ & $\%$ & & \\
\hline Students participate in problem-solving. & 134 & 87.0 & 6 & 3.9 & 14 & 9.1 & 1.22 & 0.59 \\
\hline $\begin{array}{l}\text { Teacher involves students } \\
\text { discussing climate related issues. }\end{array}$ & 154 & 100.0 & 0 & 0 & 0 & 0 & 3.00 & 0.00 \\
\hline Teacher uses Illustrated talks. & 123 & 79.9 & 0 & 0 & 31 & 20.1 & 1.40 & 0.80 \\
\hline Students are engaged in role play. & 149 & 96.8 & 0 & 0 & 5 & 3.2 & 1.06 & 0.36 \\
\hline $\begin{array}{l}\text { Teacher engages students } \\
\text { brainstorming. }\end{array}$ & 141 & 91.6 & 3 & 1.9 & 10 & 6.5 & 1.15 & 0.51 \\
\hline Teacher makes use of resource person. & 146 & 94.8 & 0 & 0 & 8 & 5.2 & 1.10 & 0.45 \\
\hline $\begin{array}{l}\text { Students work in groups on } \\
\text { different topics } \\
\text { presentations. }\end{array}$ & 131 & 85.1 & 2 & 1.3 & 21 & 13.6 & 1.29 & 0.69 \\
\hline
\end{tabular}

Source: Field Data, 2019

In view of this, Dynneson and Gross (1999) assert that discussion method is one of the most frequently used technique in Social Studies lessons. A similar view is shared Kwenin (2010) who believes that Social Studies 
teachers mostly use the discussion method due to the fact that it encourages class participation, places students at the center of the learning processes, ensure that knowledge acquired by students are retained and makes learning practical and meaningful. With respect to students participating in role play, students are encouraged to learn through dramatization by expressing in their own words the drama of the event. Thus, if teachers employ role play in teaching climate-related concepts, students will not only actively participate in the lesson but will also enable them apply the lesson to real life situations. ASESP (1990) asserts that many teachers seriously use roleplay technique because it compels students to be actively involved in historical, political, or social events.

The views of the respondents in the interview also support the outcome of information gathered with the questionnaire. Three of the interviewees were of the view that the practical nature of climate related issues requires more practical and pragmatic methods of teaching in order to adequately equip students to tackle the problem from diverse angles. For instance, one of the interviewees said that, "climate change is real, and the problem emanates from a lot of human actions such as the use of old age vehicles, high rate of $\mathrm{CO}_{2}$ concentration in the atmosphere which is mostly caused by human activities. So I believe that in order to teach students how to correct the challenges posed by climate change, they must be taken through practical teaching methods. They must be exposed to the very things that cause climate change and asked to address them practically, or else, we won't get anywhere". Another interviewee rather indicated that "... yes, as for the methods of teaching they are plenty but the question is how effective are the methods? Since the effect of climate change is on a large scale, sending students to the places whose activities endanger the climate will be a move in the right direction".

Another interviewee was of the view that "active engagement of students in discussing the possible humanrelated causes of climate change, it will be of great impact. The issue is if one does not know what causes climate change, what the effects are and the possible measures that could be put in place to mitigate it, then it becomes difficult for one to address it so for me I thing active engagement will help". The use of discussion to teach climate related concepts by teachers is not surprising since it encourages active learner participation and ensures problems and issues are effectively dealt with by an entire class.

The peculiar nature of Social Studies calls for effective teaching techniques and strategies that will facilitate comprehension of concepts, develop and encourage participation and critical as well as reflective thinking. Thus, the social studies teachers are well grounded in different methods of teaching and also possess the requisite knowledge in varied subjects for effective teaching. However, their ability and competences in integrating these teaching techniques in an effective manner to enhance learners' understanding of the concept of climate challenges is most crucial.

Perception of teachers on the challenges of Social Studies in addressing climate change

This section sought to explore perceptions on Social Studies education in addressing climate-related challenges. The outcome of their views is presented in Table 3.

Table 3: Perception of teachers on the challenges of the Social Studies in addressing climate change

\begin{tabular}{|c|c|c|c|c|c|c|c|c|}
\hline \multirow{2}{*}{$\begin{array}{l}\text { Perception of teachers on the challenges of } \\
\text { the Social Studies in covering climate } \\
\text { change }\end{array}$} & \multicolumn{2}{|c|}{ Agree } & \multicolumn{2}{|c|}{ Neutral } & \multicolumn{2}{|c|}{ Disagree } & \multirow[t]{2}{*}{ Mean } & \multirow[t]{2}{*}{ Std dev. } \\
\hline & $\mathbf{N}$ & $\%$ & $\mathbf{N}$ & $\%$ & $\mathbf{N}$ & $\%$ & & \\
\hline $\begin{array}{l}\text { Large number of students in a crowded } \\
\text { classroom. }\end{array}$ & 148 & 96.1 & 0 & 0 & 6 & 3.9 & 1.08 & 0.39 \\
\hline Inadequate teaching resources. & 130 & 84.4 & 8 & 5.2 & 16 & 10.4 & 1.26 & 0.63 \\
\hline Less conducive classrooms. & 127 & 82.5 & 4 & 2.6 & 23 & 14.9 & 1.32 & 0.72 \\
\hline $\begin{array}{l}\text { Poor funding of Social Studies education in } \\
\text { Ghana. }\end{array}$ & 144 & 93.5 & 2 & 1.3 & 8 & 5.2 & 1.12 & 0.46 \\
\hline Lack of teacher competency in teaching Social & & & & & & & & \\
\hline Studies. & 152 & 98.7 & 0 & 0 & 2 & 1.3 & 1.03 & 0.23 \\
\hline $\begin{array}{l}\text { Inadequate content to cover climate change } \\
\text { topics. }\end{array}$ & 153 & 99.4 & 0 & 0 & 1 & 0.6 & 1.01 & 0.16 \\
\hline $\begin{array}{l}\text { Difficulty in using integrated approach to } \\
\text { teach social studies. }\end{array}$ & 139 & 90.3 & 2 & 1.3 & 13 & 8.4 & 1.18 & 0.57 \\
\hline $\begin{array}{l}\text { Lack of well-furnished Social Studies } \\
\text { laboratory. }\end{array}$ & 142 & 92.2 & 0 & 0 & 12 & 7.8 & 1.16 & 0.54 \\
\hline
\end{tabular}

Source: Field Data, 2019

Results from Table 3 points to the fact that the Social Studies curriculum faces a lot of challenge which impede its efforts towards the realization of one of its environmental objectives: mitigating climate change. For instance, the outcome shows that teachers $(\mathrm{N}=154, \mathrm{M}=1.26, \mathrm{SD}=0.63)$ agreed that inadequate learning resources as posing major problem to the teaching climate related issues in social studies. In the view of Kwenin (2010), the use of instructional materials is one of the most significant developments in the field of teaching. Students 
learn through their senses which create impressions on their minds by arousing and stimulating attention. Thus, in order to realize the aims and goals of citizenship education, a wide array of multi-media resources which appeal to all senses of students must be employed in teaching and learning citizenship education.

The teachers $(\mathrm{N}=154, \mathrm{M}=1.03, \mathrm{SD}=0.23)$ also agreed that lack of teacher competency in handling Social Studies could negatively affect the teaching of social studies. This could stem out of insufficient teacher preparation which could pose major challenges in teaching. This inadequacy relates not only to a lack of teacher content knowledge but also to an inability to employ a range of teaching and learning approaches appropriately for citizenship education. It is common knowledge that untrained teachers or trained teachers who do not have any background knowledge in Social Studies could use their experience and knowledge from other subjects to teach social studies.

The findings $(\mathrm{N}=154, \mathrm{M}=1.08, \mathrm{SD}=0.39)$ also show that large number of students who are crowded in the classroom hinders efforts towards the teaching and learning of climate related issues in social studies. Large class size has been found to be a major challenge for effective teaching. Teachers who handle classes that large hardly get adequate time and space to effectively interact with students and adequately address the individual differences that exist among students. It puts unbearable pressure on them and overburdens them.

\section{Challenges of Social Studies education in responding to climate-related issues}

Respondents were also interviewed on challenges that hinder Social Studies education in addressing climaterelated issues. The interviewees mentioned a number of challenges that affect teaching of Social Studies towards addressing climate-related issues. In the view of one of the teachers, "most teachers are not trained in Social Studies education so they find it difficult teaching it, attaining the environmental aim of Social Studies becomes a different thing all together". It is clear from this view that teachers who are not well-grounded in Social Studies education will find it difficult teaching the content effectively. This is because the content of Social Studies education cuts across several related disciplines such as geography, economics, history, etc. Another teacher also indicated that "the nature of teaching in Ghana is more on the content and how students will pass examinations so we teach content with little or no emphasis on its practicability. So how can they [students] acquire the needed information to mitigate climate challenges? Another interviewee also indicated that "to effectively teach climate related issues in social studies, one needs to lay hands on appropriate TLRs but here is the case where teachers do not use any materials. So teaching is always done in abstract, divorce from the real world". A similar view was shared by another interviewee who said that "teaching climate change requires videos, diagrams, pictures and so on but in our situation, these things are missing so how do you expect us to do any meaningful teaching?"

Others were also of the view that "we teach what is contained in the syllabus. We cannot digress from what GES has instructed us to teach. So if climate is not found in the syllabus, then don't expect any teacher to teach it. At best we can cite examples outside the syllabus but even with that one, the examples must relate to the content of the syllabus". This view is in support of the views expressed by Wise (2010) that in the context of climate change inclusion in the Social Studies curriculum, there is the need to realign existing curriculum to effectively provide the requisite knowledge and training to help learners to respond climate-related challenges.

Another challenge that was revealed related to the time available for teachers to complete the Social Studies syllabus with reasonable time period. In relation to this, one teacher said that "the time is too limited such that I find it difficult to complete my syllabus. So, if you want to engage your students in other equally relevant activities like fieldtrip and the likes, the whole term will end and you have done nothing. So, time available is a big issue looking at other numerous sporting activities". These challenges have the tendency to cripple the Social Studies curriculum in mitigating climate related .challenges

\section{Recommendations for mitigating climate change challenges}

Integration of more climate related topics and issues in a transdisciplinary manner into the Social Studies and other related curricula such as science, citizenship education, geography and human rights education, at the various levels of education in Ghana will be of great help. This should largely focus on the development of knowledge, skills and competencies needed to contribute to the mitigation of and adaptation to climate change. This will ensure that learners are adequately taken through the various issues related to climate change such as the causes, effects and mitigation strategies of climate change. It will also provide adequate grounds for environmental literacy among students and enable them apply knowledge and skills to their real life situations.

It is also recommended that teacher education institutions that prepare Social Studies teachers at the various levels of higher education in Ghana such as the colleges of education and the universities should adequately include climate change related topics in their curriculum. It is crucial to strengthen teachers' and educators' capacities to deliver accurate information, integrate local content, promote critical thinking on climate change and take action on climate change mitigation and adaptation. Thus, for teachers to be able to teach climate change effectively, they are required to understand the implications of such change, recognize the causes of it 
and have the competence and confidence to introduce it into their lesson plans. This will help to adequately equip the teacher trainees with knowledge and experiences which are pre-requisites for effective transmission of knowledge and inculcation of skills and attitudes for climate education. It is only when teachers have been equipped adequately to understand what climate change implies, recognize the need for it, and have the competence and confidence to introduce new methods and approaches to climate change that they would be able to teach their students effectively on measures to mitigate climate change.

Provision of appropriate and suitable teaching and learning resources would also help in bringing reality to the teaching and learning of Social Studies in Ghana. This will enable teachers in enhancing and facilitating learners' understanding and applicability in tackling climate-related challenges in their communities. Teaching and learning resources such as climate charts, globes, documentaries, videos, and pictures on the impact of climate change and ways of mitigating the challenges of climate change should be made available.

The use of appropriate methods of implementing the Social Studies curriculum such as the integrated approach would enable teachers to select appropriate content areas from climate related subject areas for effective teaching. The selection and integration in transdisciplinary manner suitable theories, principles, laws, experiences and skills from varied subject areas would constitute an effective means of addressing the challenges of climate change and help provide holistic body of knowledge, experiences and skills to students. This, when done at all levels of education in Ghana, will in turn result in the total development of students and properly position them to effectively deal with climate related issues. Also, engaging students in practical activities would promote problem solving skills, and develop students' ethical attitudes towards environmentally sustainable practices.

\section{Conclusions}

The findings from the study indicate that the Social Studies curriculum at the JHS level does not adequately cover climate related issues. Although Social Studies education focuses on the physical environment and helps to address environmental challenges, one would expect that the curriculum would make adequate provision of such a critical component of environment, but this is not the case as the curriculum covers less environmental-related issues.

Although Social Studies teachers are the front liners when it comes to implementing climate related issues in the Social Studies curriculum, they are not adequately equipped in knowledge, skills and competencies required for effective transmission of same to learners. At best, some of the teachers had climate-related knowledge from subjects other than social studies, the knowledge they had acquired was not sufficient enough for their effective application in the classroom.

The various methods used in implementing the Social Studies curriculum are usually the discussion method, field study, brainstorm and the problem solving methods. It is believed that when these methods are adequately used in teaching Social Studies, learners would adequately be equipped with knowledge and skills in addressing the challenges posed by climate change. However, if these methods are effectively combined and linked up with the content of climate change, which is inadequate in the curriculum, the realization of the environmental focus of Social Studies education will not materialize. Teachers at times also over rely on few methods to the disadvantage of others.

Although Social Studies is environmentally focused, it becomes difficult for the subject to attain its objectives. The growing size of students' body which results in larger class sizes does not offer teachers the opportunity to adequately interact with students in diverse ways in order to address individual students needs and differences among them. Another perceived challenge that hinders effective realization of climate change education through Social Studies education is the use of obsolete teaching and learning resources for the teaching and learning of social studies. In some cases, both teachers and learners do not employ teaching and learning resources during the teaching session. The implication is that learners are unable to translate into practices, concepts and theories that are taught in a Social Studies class. All these factors hinder the curriculum in responding to climate challenges.

\section{References}

Ary, D., Jacobs, L. C., Razavieh, A., \& Sorensen, C. (2006). Introduction to research in education (7th ed.). Belmont, CA: Thomson Higher Education.

Athman, J., \& Monroe, M. (2004). The effects of environmental-based education on students' achievements motivation. Journal of Interpretation Research, 9 (1), 9-25.

Babbie, E. (2007). The practice of social research (1 $1^{\text {th }}$ ed.). Belmont, CA: Thomson- Wadsworth.

Banks, J.A. (2000). An introduction to multicultural education. Boston: Allyn and Bacon.

Benavot, A. (2002). A critical analysis of comparative research: Education for learning to live together. Prospects, 32, 51-73.

Best, J., \& Kahn, J. (1998). Research in education (8th ed.). Boston: Allyn and Bacon 
Çelikler, D., \& Aksan, Z. (2011). Determination of pre-service elementary science teachers' knowledge level about ozone layer. Procedia-Social and Behavioral Sciences, 15, 1438-1444.

Cobbold, C. \& Kwenin, I. A. (2020). The natural environment. College of Distance Education, University of Cape Coast, Cape Coast, Ghana.

Creswell, W. (2003). Research design: Qualitative, quantitative and mixed methods approach (2 ${ }^{\text {nd }}$ ed.). Thousand Oaks. Sag Publishers.

Dove, J. (1996). Student teachers' understanding of the greenhouse effect, ozone layer depletion, and acid rain. Environmental Education Research, 2, 89-100.

Dynneson, T.L. \& Gross, R. E. (1999). Designing effective instruction for secondary social studies (2nd ed.). Prentice Hall Inc., Upper Saddle River, NJ.

Gall, M. D., Borg, W. R., \& Gall, J. R (1996). Educational research: An introduction (6th ed.). New York, NY: Longman.

Fraenkel, J. R \& Wallen, N. E. (1996). How to design and evaluate research. USA: Mc. Fraw-Hill Inc.

Fortner, R. W. (2001). Climate change in school: Where does it fit and how ready are we? Canadian Journal of Environmental Education, 6, 18-31.

Ghana Education Service (GES). (2010). Social studies syllabus for senior high schools. Accra: GES.

Greenleaf, E. A. (1992). Measuring extreme response style. Public Opinion Quarterly, 56(3), 328-351.

Intergovernmental Panel on Climate Change (IPCC), (2008). Climate change 2001: The scientific basis. Contribution of working group I to the third assessment report of the intergovernmental panel on climate change. Cambridge University Press, 881.

Jasim, B. (2008). Mastering social Studies for junior high schools. Accra: Excellent Publishing \& Printing.

Johnson, R. B., Onwuegbuzie, A. J., \& Turner, L. A. (2006). Toward a definition of mixed methods research. Journal of Mixed Methods Research, 1 (2), 112-133.

Karl, T. R., Melillo, J. M., \& Peterson, T. C. (Eds). (2009). Global climate change impacts. New York: Cambridge University Press

Kimmon, S. (1990). Theoretical statistics. Acron: Mimeograph.

Kwenin, I. A. (2010). Students' and teachers' perception of citizenship education in social studies in selected senior high schools in the Kumasi Metropolis. Unpublished master's thesis. University of Cape Coast, Cape Coast.

Kwenin, I. A. (2019). The integrated nature of social studies: Pedagogical implications. International Journal of Innovation and Research Development, 8 (9), 230-240.

Linquist, T. (1995). Seeing the whole through social studies. Portmouth NH: Hienemann

Manstrandrea, M. D. \& Schneider, S. H. (2009). Global warming. Microsoft ${ }^{\circledR}$ Encarta ${ }^{\circledR}$ Online Encyclopedia.

Martorella, P. H. (1994). Social studies for elementary school children: Developing young citizens. Englewood Cliffs, New Jersey: Prentice Hall.

Ministry of Education, Science and Sports, [MESS]. (2007). Teaching syllabus for social studies - Senior high school (SHS). Accra: MESS.

National Center for History in the Schools. (1994). National standards for world history: Exploring paths to the present. Los Angeles: National Center for History in the Schools.

National Council for the Social Studies. (1979). Revision of the NCSS social studies curriculum guidelines. Social Education, 43, 261-278.

National Council for the Social Studies. (1994). Expectations of excellence: curriculum standards for social studies. Washington, DC: National Council for the Social Studies.

Nwankwo, C. A., \& Unachukwu, G. O. (2012). Teachers' awareness of the causes and effects of climate change and their classroom management strategies in climate change era. Research Journal in Organizational Psychology \& Educational Studies, 1 (3), 161-167.

Ochieng, M. A., Koske, J. (2013). The level of climate change awareness and perception among primary school teachers in Kisumu Municipality, Kenya. International Journal of Humanities and Social Science, 3 (21), $174-179$

Okoro, N. J. (2004). The role of sex in education achievement. Journal of Teachers Perspective, 4(2), 12-14.

Papadimitriou, V. (2004). Prospective primary teachers' understanding of climate change, greenhouse effect, and ozone layer depletion. J. Sci. Educ.Technol., 1 (2), 299-307.

Parasuraman, A., Zeithaml, V. A. \& Berry, L. L. (1988). A multiple item scale for measuring consumer perceptions of service quality. Journal of Retailing, 64, 1, 14-40

Resnik, J. (2006). International organizations, the "education-economic growth" black box, and the development of world education culture. Comparative Education Review, 50 (2), 173- 195.

Shrivastava, K.K. (2006). Environmental education: Principles, concepts and management. New Delhi: Kanishka Publishers and Distributors.

Singleton, C. H., Thomas, K. V., \& Leedale, R. C. (1996). Lucid CoPs cognitive profiling system. Beverley, East 
Yorkshire: Lucid Research Ltd.

Svihla, V. \& Linn, M. C. (2012). A design-based approach to fostering understanding of global climate change. International Journal of Science Education, 34 (5), 651- 676.

Tamakloe, E. K. (Ed.). (1994). Issues in social studies education. Accra: Black Mask Ltd. Tamakloe, E. K. (1991). The nature of social studies and its curriculum implications. Journals of Institute of Education, 2 (1), 47-48.

Wise, S.B. (2010). Climate change in the classroom: Patterns, motivations and barriers to instruction among Colorado science teachers. Journal of Geoscience Education, 58 (5), 297-309. 